\title{
Microfluidic Devices for Label-Free DNA Detection
}

\author{
Gorachand Dutta, Joshua Rainbow, Uros Zupancic, Sotirios Papamatthaiou@, Pedro Estrela *(D) \\ and Despina Moschou *(1)
}

Centre for Biosensors, Bioelectronics and Biodevices (C3Bio) and Department of Electronic \& Electrical Engineering, University of Bath, Bath BA2 7AY, UK; G.Dutta@bath.ac.uk (G.D.); jr993@bath.ac.uk (J.R.); U.Zupancic@bath.ac.uk (U.Z.); S.Papamatthaiou@bath.ac.uk (S.P.)

* Correspondence: P.Estrela@bath.ac.uk (P.E.); D.Moschou@bath.ac.uk (D.M.); Tel.: +44-012-2538-3245 (D.M.)

Received: 2 August 2018; Accepted: 18 September 2018; Published: 25 September 2018

\begin{abstract}
Sensitive and specific DNA biomarker detection is critical for accurately diagnosing a broad range of clinical conditions. However, the incorporation of such biosensing structures in integrated microfluidic devices is often complicated by the need for an additional labelling step to be implemented on the device. In this review we focused on presenting recent advances in label-free DNA biosensor technology, with a particular focus on microfluidic integrated devices. The key biosensing approaches miniaturized in flow-cell structures were presented, followed by more sophisticated microfluidic devices and higher integration examples in the literature. The option of full DNA sequencing on microfluidic chips via nanopore technology was highlighted, along with current developments in the commercialization of microfluidic, label-free DNA detection devices.
\end{abstract}

Keywords: DNA; biosensor; label-free; microfluidics; Lab-on-Chip

\section{Introduction}

The rapid technological progress of the past couple of decades in the fields of biosensors and microfluidics [1], has allowed the originally envisioned democratization of healthcare of the early 1990s [2] to be closer to realization than ever. A broad range of different biosensing concepts and microfluidic structures currently allows the qualitative or quantitative detection of various biomarkers of clinical interest. With DNA biomarkers [3,4] increasingly being identified and associated with a very broad spectrum of clinical diseases (e.g., cancer, infectious disease, antimicrobial resistance, etc.), intense scientific effort has been focused on their sensitive and specific detection. With the ultimate goal being affordable, easy to use and small footprint DNA diagnostic microsystems, microfluidic structure integration for sample pre-processing and automated reagent handling are some of the critical aspects being investigated currently [5]. Simplicity in device functionality is critical, aspiring for robust and reliable diagnostic microsystems; to this end, simplification of the biosensing assay by removing the need for any additional labelling step [6,7] can provide a step-change in the development of tests ready for mass deployment.

Therefore, in this review our goal is to present recent developments in label-free DNA biosensors, with a particular focus on integration with microfluidic structures. We classified the microfluidic devices based on the integrated microfluidic structure complexity, starting from the simplest approach of flow-cell integration. Given the number of interesting flow-cell integrated structures, they were sub-classified using the biosensing principle employed. We then proceeded to more complicated microfluidic structures for label-free DNA biosensing platforms, higher integration examples, and state-of-the-art nanofluidic-based DNA sequencers. We conclude with the commercialization efforts currently being pursued in the field. It is worth noting that our definition of label-free detection involves techniques that do not require the attachment of any additional molecule on the target 
DNA sequence; hence techniques involving the use of reagents diluted in solutions for measurement purposes, are still considered to be label-free.

\section{Flow-Cell Biosensing Approaches}

Over the past two decades label-free biosensing has seen an unprecedented development in advancement from macro, to micro, to nanotechnology [8]. This improvement in the miniaturization of sensing technology would not have been possible without the integration of microfluidics [9]. Nonetheless, the field of biosensing still has a long way to go to meet the requirements of commercialization, for application in bed-side diagnostics [10]. Technologies for the label-free detection of DNA hybridization utilizing microfluidic structures to deliver the analytes exploit optical, electrochemical, as well as mass-based sensing concepts.

\subsection{Optical}

Optical approaches in biosensing are a promising area of analysis tools, which have received considerable research interest for label-free DNA detection. The advantages of optical biosensing systems include not only their inherent resistance to electromagnetic interference, but also their low limits of detection (LOD) at both the micro and nano scales, and the ability to perform multiple analyte detections within a single Lab-on-Chip (LOC) device [11-13].

Surface plasmon resonance (SPR) is the most well-known optical technique for real-time, label-free characterization of binding kinetics and affinity. It involves the determination of the resonant oscillation of conduction electrons at the interface between negative and positive permittivity material, stimulated by incident light. The first SPR biosensing device demonstrated by Liedberg et al. in 1983 [14], established SPR as an important optical method for the detection of bio-recognition molecules. The last decade has seen extensive studies of this now ubiquitous laboratory technique, as well as the development of a number of SPR devices for DNA hybridization detection [13].

In 2017 Yuan et al. [15] demonstrated the use of a highly sensitive label-free SPR-DNA sensor utilizing in situ synthesized copper nanoparticles (CuNPs), by terminal deoxynucleoside transferase (TdT)-mediated DNA prolongation form-logic ideology (Figure 1). Using this method, a highly-sensitive LOD of $3.2 \mathrm{fM}$ was achieved under flow-injection rates of $10 \mu \mathrm{L} \mathrm{min}{ }^{-1}$.

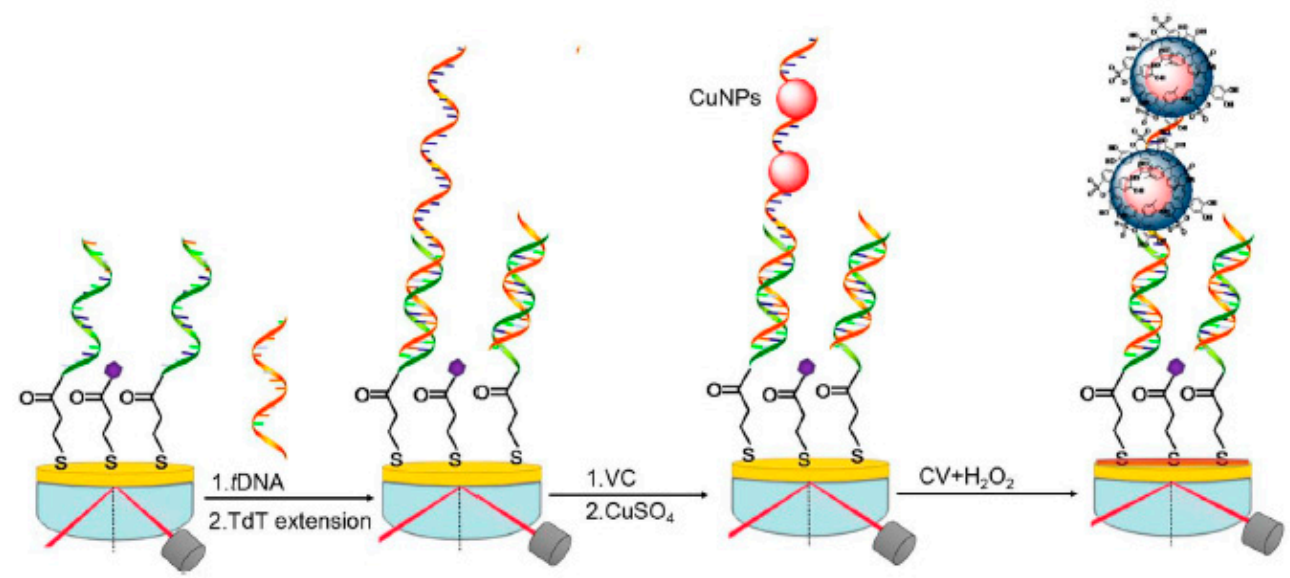

Figure 1. Schematic drawing of the synthesis of CuNPs templated by TdT-mediated DNA (Reprinted from Yuan et al. [15]. Copyright (2017), with permission from Elsevier).

The development of an SPR-based sequence-specific microfluidic chip was reported by Kurita et al. in 2015 [16], for the immunochemical detection of DNA methylation. The group reports the use of an affinity measurement involving a target (methyl)-cytosine, within a single-base bulge region. The target was flowed through a microfluidic channel containing anti-methylcytosine antibody, followed by hybridization with a biotinylated bulge-inducing DNA probe on the surface of gold. Results showed 
significantly high DNA methylation assessment ( 6 amol or $48 \mathrm{fg}$ ); they also discriminated between the methylation status of single cytosine in genomic $\lambda$ DNA and HCT116 human colon cancer cells.

Localized surface plasmon resonance (LSPR) is another approach that has received attention due to its advantage of localized-field phenomenon, which allows for lower levels of background interference. Unlike SPR, LSPR instrumentation is also less complex, not requiring a prism or a grating coupler for excitation of propagating plasmons [13]. This low complexity of instrumentation allows for the increased portability and miniaturization of LSPR sensors, as well as cost effectiveness [17].

Another study by Huang et al. in 2012 exploited the characteristic LSPR properties of gold nanorings in an on-chip microfluidic device, for the real-time detection of label-free DNA. Singlestranded DNA (ssDNA) probes were immobilized onto the surface of the sensor. Complementary target DNA was then passed through two inlets into a sensing chamber to be analyzed using LSPR, before passing through to waste reservoirs, and finally out of the device through two outlets. Using this method of gold nanorings, a wavelength shift of $8.2 \mathrm{~nm}$ was observed upon DNA probe immobilization, followed by a $3.1 \mathrm{~nm}$ shift after DNA hybridization. Thus, effectively coupling both a label-free nanosensor technique with a microfluidic platform. Interferometric techniques, such as bimodal, Mach-Zehnder, and micro ring resonators, could also be used for label-free DNA detection [18-20]. Song et al. 2016 [19] reported a microfiber-assisted Mach-Zehnder interferometer (MAMZI) for label-free DNA detection. The interferometric spectrum of the proposed microcavity sensor was highly sensitive to variation of the environmental refractive index (RI), and could be applicable for most biological applications.

Surface-enhanced Raman spectroscopy (SERS) based microfluidic platforms have also been presented in the literature, referred commonly as lab-on-chip SERS (LoC-SERS) or nano/micro/ optofluidic SERS [21]. A growing number of applications of microfluidic SERS analysis related to DNA biosensing has been developed [22], citing its extraordinary sensitivity towards different targets in a large range of concentrations, exploiting $\mathrm{nL}$ volume samples. Qi et al. [23] presented a microfluidic SERS system, approaching single molecule sensitivity when monitoring DNA hybridization. Current efforts focus on specific multiplex detection of small oligonucleotides, by improving the SERS substrate properties with nanotechnology [24].

\subsection{Electrochemical}

Recently, electrochemical biosensors have become one of the biggest and most studied approaches to biological sensing $[8,25,26]$. This is due to their low levels of detection, inexpensive running costs, and simple instrumentation relating to ease of miniaturization, making electrochemical methods highly attractive for the development of point-of-care diagnostic devices.

A Bio-FET is a field-effect transistor (FET), which is gated by the surface potential change induced by the binding of (bio)molecules. Devices based on field-effect transistors have attracted great attention because they operate as an intrinsic amplifier, converting small changes in surface potential to large changes in the current without the need for additional circuitry. The dielectric material (FET gate dielectric) changes the charge distribution of underlying semiconductor materials when biomolecules bind to the FET dielectric or gate electrode, resulting in a change in conductance. Moreover, no labeling step is required for Bio-FET, making it more suitable for point-of-site detection, such as medical diagnostics, biological research, environmental monitoring, and food analysis because of its low weight, low cost of mass production, small size, compatibility with commercial planar processes for large-scale circuitry, and possibility of integration into microfluidic devices for Lab-on-Chip [27].

An example of a microfluidic integrated label-free DNA FET was created by $\mathrm{Xu}$ et al. [28] on a printed circuit board. An 8-channel FET DNA sensor array was fabricated from chemical vapour deposition (CVD) graphene, and each graphene site in the array was used for two purposes: First, as a sensing FET, and second, as an electrophoretic electrode to enable site-specific immobilization of probe DNA (Figure 2). The site-specific single-stranded target DNA was detected in the femtomolar level $(\mathrm{LOD}=100 \mathrm{fM})$ upon hybridization, and each graphene was used as a FET. By using an 
8-graphene-electrode/FET array with a microfluidic channel on top, it makes the device suitable for multiplex DNA detection.

a
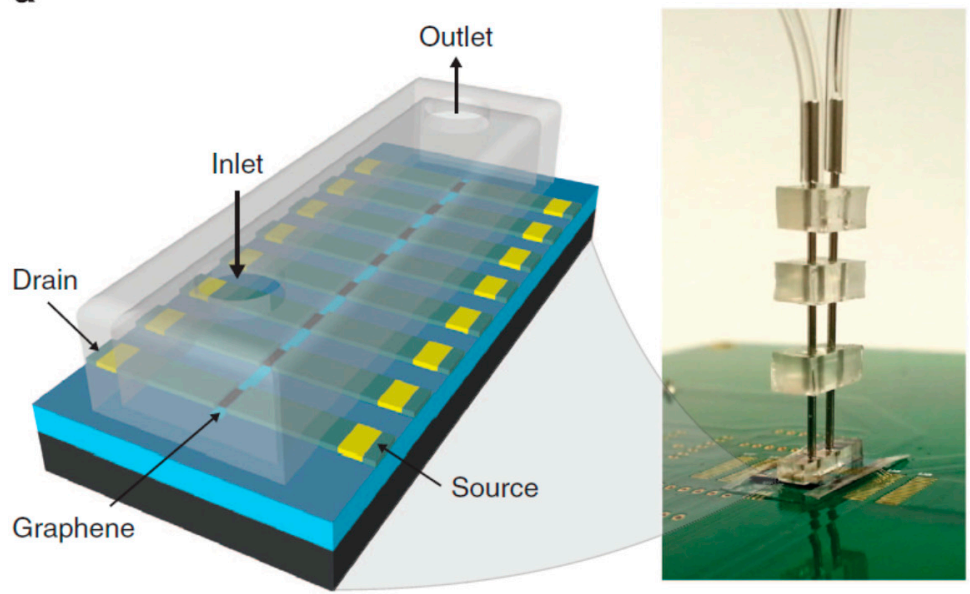

b

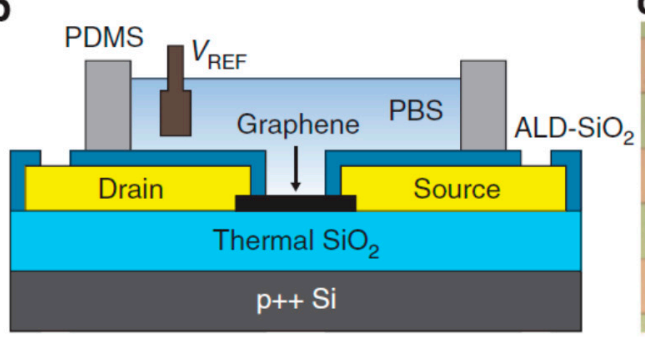

C
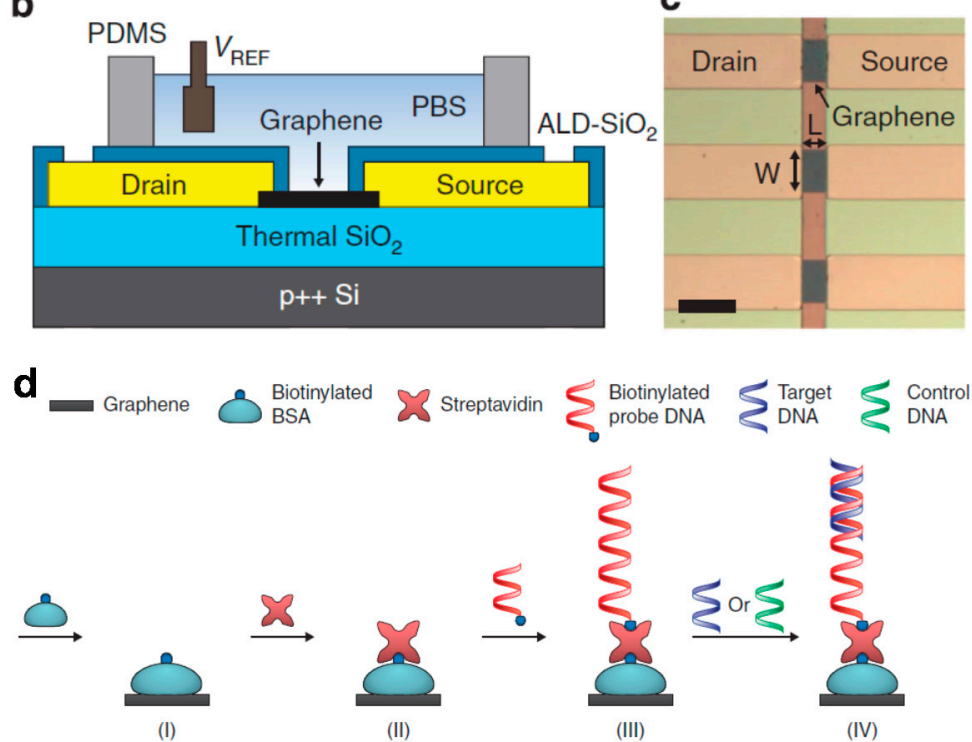

(II)

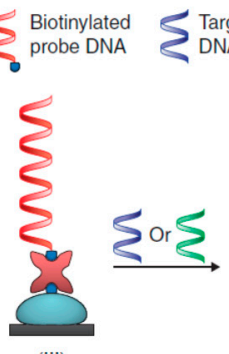

(III)

Figure 2. (a) Image of an 8-graphene-electrode/FET array with a microfluidic channel. (b) A crosssectional view of an individual graphene site. (c) Optical image of a fabricated graphene array. (d) Schematic illustration of site-specific probe DNA immobilization and target detection. (I \& II) BSA-streptavidin surface functionalization, (III) non electrophoretic probe DNA immobilization, and (IV) hybridization or control experiments (Reprinted from Xu et al. [28]. Copyright (2014), with permission from Springer Nature).

Electrochemical impedance spectroscopy (EIS) is a ubiquitous characterization technique used in biosensing laboratories to detect the non-linear response of an electrochemical system to an applied potential, revealing underlying biological recognitions events.

An example of an EIS-based system was demonstrated by Ben-Yoav et al. [29], who developed a microfluidic EIS-based biochip for the detection of DNA hybridization (DNA/DNA). The biochip was composed of three micro-channels on an arrayed electrochemical micro-chip (Figure 3). Probe ssDNA was immobilized on both gold and platinum, using mercaptohexanol $(\mathrm{MCH})$ as a back-filler. Target ssDNA was then exposed to probe ssDNA under flow within a $\left[\mathrm{Fe}(\mathrm{CN})_{6}\right]^{3-/ 4-}$ redox couple in phosphate buffered saline (PBS) solution. Using this method, a LOD of $3.8 \mathrm{nM}$, and a selectivity of $13 \%$ hybridization with other non-complementary DNA was demonstrated. 


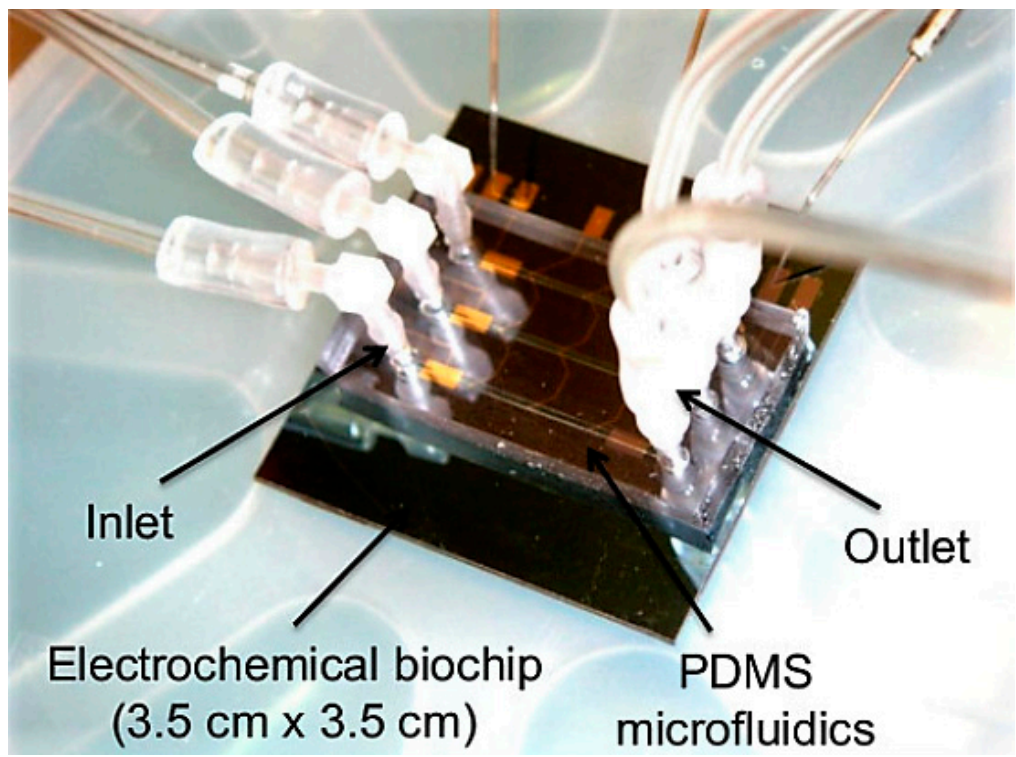

Figure 3. Tested microfluidic device (dimensions: $3.5 \mathrm{~cm} \times 3.5 \mathrm{~cm}$; micro-channel height of $100 \mu \mathrm{m}$, width $500 \mu \mathrm{m}$ ) (Reprinted from Ben-Yoav et al. [29]. Copyright (2012), with permission from Elsevier).

Open circuit potential (OCP) utilizes the change in the net charge of an electrode surface. A study by Jolly et al. [30] implemented both OCP and EIS to detect PNA/DNA hybridization with sample amplification by gold nanoparticles (AuNPs). Peptide nucleic acid (PNA) probes, used for their inherent neutral charge, were immobilized onto the surface of a gold working electrode. PNA/DNA hybridization was then measured by OCP and EIS in real-time with a three electrode set-up (Figure 4). Using the current system, a LOD of $1 \mathrm{fM}$ was achieved with significant increases in capacitance due to use of AuNPs.

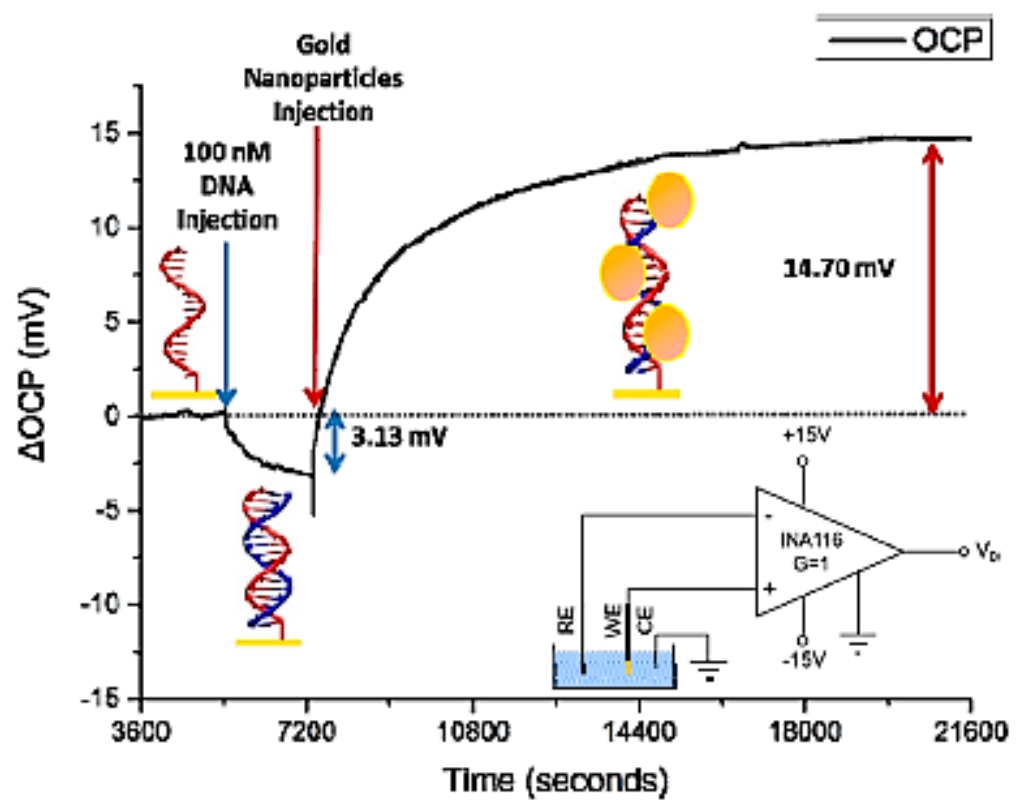

Figure 4. Open circuit potential (OCP) measurements of PNA/DNA hybridization in real-time (@) [2015] IEEE. Reprinted, with permission, from Joly et al. [30]).

A label-free EIS-based biosensor chip was demonstrated by Wu et al. 2015 [31], for the detection of DNA hybridization. This device was integrated with microfluidic DC-biased AC electroosmotic (ACEO) stirring, utilizing concentric double ring-single disk electrodes to increase hybridization events. 
Thiol-modified probe DNA was immobilized onto the surface of gold disk electrodes (DE) to form Au-S bonds. Target DNA was then hybridized under ACEO stirring and measured using EIS and OCP. EIS was used to measure changes upon DNA hybridization, and OCP for characterization of the probe-MCH layer. Using this method, a detection range of $1 \mathrm{aM}-10 \mathrm{pM}$ with good linearity was demonstrated, alongside an ultrasensitive LOD of 0.5 aM. Furthermore, a $90 \%$ hybridization saturation was achieved using the ACEO stirring method within $141 \mathrm{~s}$.

\subsection{Mass-Based}

Another approach to biosensing, which has seen less recent activity in microfluidic research, is the mass-based signal transduction methods (for example, quartz crystal microbalance (QCM) and surface acoustic waves (SAW)). These methods are unique in biosensing, as they rely on the change in mass occurring when a target analyte binds to an immobilized probe. The major advantages of mass-based sensors are the high sensitivity and robustness with which they detect biological recognition events, making them suitable for detection at the micro and nano level [8].

An example of the robust nature of mass-based sensors was presented by Hong et al. in 2010 [32], comprising a QCM biosensor integrated with piezoelectric wafer layer wells and syringe pumps, for label-free detection of viral hemorrhagic septicemia (VHS). DNA probes were immobilized onto the gold-coated quartz surface of the sensor using different thiol, amine, and biotin $3^{\prime}$ modifications, to maximize sensitivity. Both target complementary DNA and mismatched DNA was flowed through the wells using a syringe pump (flow rate of $25 \mu \mathrm{L} / \mathrm{min}$ ) during measurement. Results showed immobilization with biotin to be the most effective for both immobilization and detection of target DNA, with a LOC of $1.6 \mathrm{nM}$. The system using biotinylated probe DNA also showed high stability, withstanding 32 repeated regenerations without any significant reduction in signal generation (Figure 5).

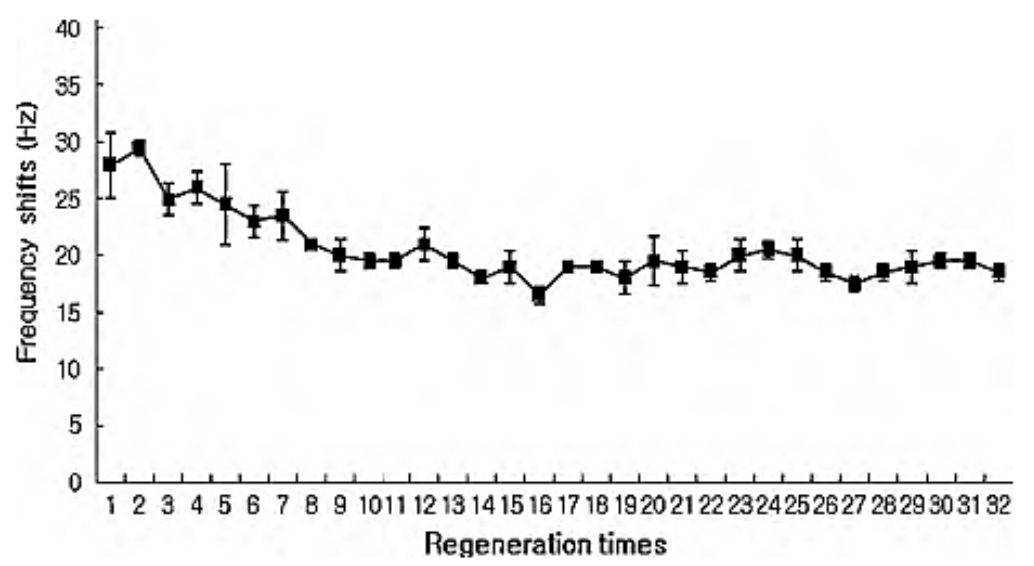

Figure 5. Regeneration test of quartz crystal microbalance (QCM) sensor utilizing biotinylated DNA probes for detection of target DNA. No significant decrease in signal was detected up to 32 regenerations (Reprinted from Hong et al. [32]. Copyright (2010), with permission from Elsevier).

García-Martinez et al. [33] developed a $50 \mathrm{MHz}$ quartz crystal microbalance (QCM)-based sensor for DNA utilizing fluid circulation for high selectivity and limit of detection (LOD). Oscillator circuitry based on Miller topology was used with circulatory flow to calibrate and detect background frequency noise and allow for high resolution $\left(7.1 \mathrm{ng} / \mathrm{cm}^{2}\right.$ under flow conditions in this study). DNA-disulfide probes were immobilized onto the gold-quartz surface within $0.5 \mathrm{M} \mathrm{NaCl}$ solution. DNA target was then hybridized under flow, followed by dehybridization solution $(0.5 \mathrm{M} \mathrm{NaOH}, 3 \mathrm{M} \mathrm{NaCl})$ (Figure 6). The study proved the DNA biosensing capabilities of the QCM oscillator with a LOD of $50 \mathrm{ng} / \mathrm{mL}$. 


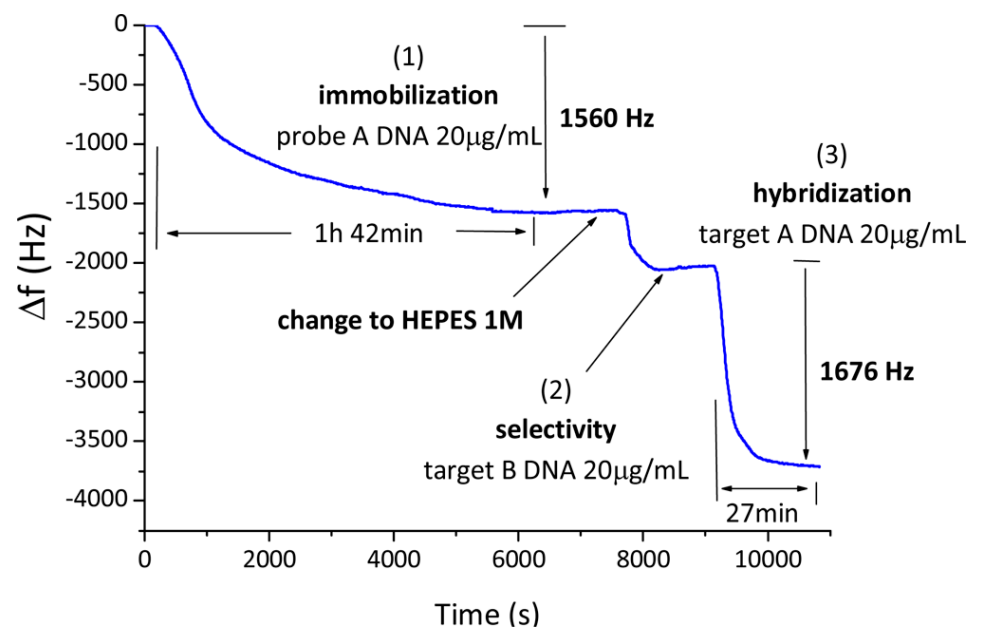

Figure 6. Frequency changes detected during circulation of DNA-disulfide probe (1), DNA target B control and DNA target A [33] (Originally published in "Development of a Mass Sensitive Quartz Crystal Microbalance (QCM)-Based DNA Biosensor Using a 50 MHz Electronic Oscillator Circuit" under Creative Commons 4.0 license).

Surface acoustic wave (SAW) devices involve mechanical waves formed on the surface of a piezoelectric crystal. SAW-based sensors have been shown to be highly selective of bio-recognition events $[34,35]$. However, studies implementing SAW for detection of DNA with high optimized frequencies are limited. Nonetheless, SAW-based devices may have the opportunity to become a major player with the prospective commercialization of medical devices that require highly sensitive, selective, and cost-effective analysis [36].

A recent study by Zhang et al. [37] proposed the use of mass-sensitive SAW technology, for the detection of amplified and sequence-specific DNA hybridization utilizing enzyme-mediated DNA elongation with silver nanoparticle synthesis in situ (Figure 7). Target DNA was hybridized with gold-immobilized probe DNA oligonucleotides (flow rate of $40 \mu \mathrm{L} / \mathrm{min}$ ). Target DNA interacted with terminal deoxynucleoside transferase (TdT) and deoxy-ribonucleoside triphosphate (dNTP) causing prolongation. The prolongation template DNA then binds with $\mathrm{Ag}^{+}$-binding DNA. Accumulated $\mathrm{Ag}^{+}$ ions then nucleated to form AgNPs. These two reactions caused a highly measurable mass increase and the synthesis of AgNPs decreasing LOD. Results suggested high sequence-specificity, even in the presence of single stranded mismatched DNA in single nucleotide polymorphism (SNP) assays. A value of $0.8 \mathrm{pM}$ was achieved for LOD due to signal amplification by AgNPs.

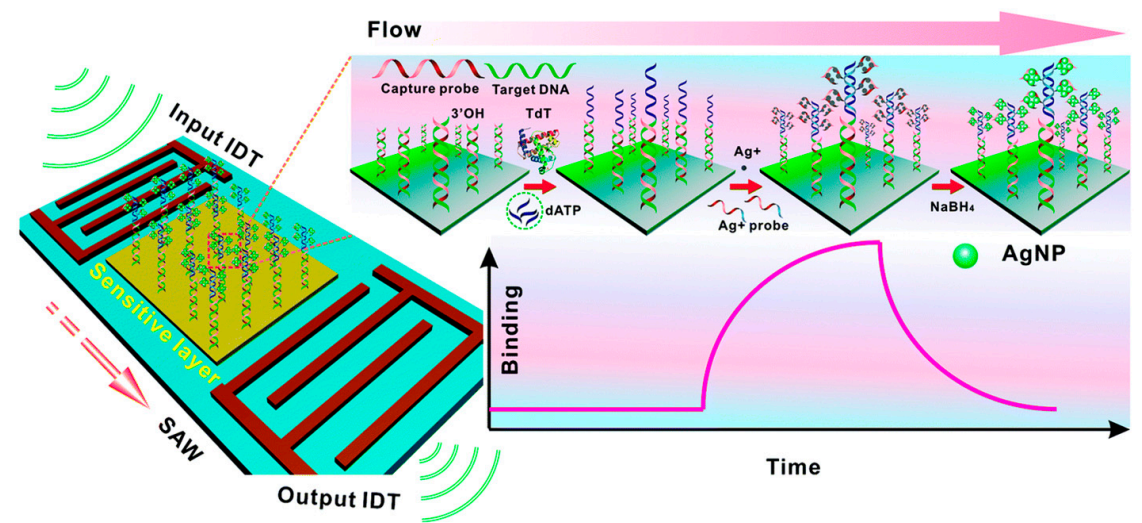

Figure 7. Surface acoustic wave (SAW)-based sensor with input and output interdigital transducer (IDT) for specific, signal-amplified DNA detection by a synergic mass increase of DNA extension and AgNPs growth in situ (Reprinted from Zhang et al. [37]. Copyright (2017), with permission from Royal Society of Chemistry). 


\section{Microfluidic Modules for Sample Preparation}

The simplest microfluidic devices integrated with label-free DNA biosensors comprise the previously analyzed approach of flow cell chambers, or channels that allow the continuous flow analysis of a pre-processed DNA sample. However, the true advantage of integrating microfluidic components with a DNA biosensor is leveraged when the sample can be pre-processed on-chip, with the incorporation of the necessary modules. In the case of DNA detection, the first sample preparation step required is the extraction of the specific DNA that needs to be detected. Depending on the sensitivity of the biosensor and the concentration of the target DNA within the sample, a DNA amplification step may also be required. Moreover, when the application requires very high throughput analysis, droplet microfluidic devices have proved to be very promising, allowing the implementation of the complete assay within a few nL liquid compartments.

\subsection{DNA Extraction}

DNA extraction microfluidic modules [38] are involved with releasing the target DNA from the cells of interest, using a variety of techniques to this end. Extracting the required DNA is currently a basic molecular biology laboratory technique [38,39], with several commercial kits in the market for standard laboratory use. The process can be roughly divided into four steps [40], which can be modulated depending on the sample and downstream applications: (i) Cell disruption; (ii) removal of membrane lipids, proteins, and other nucleic acids; (iii) nucleic acid purification/binding from bulk; and (iv) nucleic acid concentration. The advantages of using microfluidics for these processes involve the automation of laborious and time-consuming laboratory processes, minimizing human-handling errors or cross-contamination. It also allows for their integration with DNA detection modules to realize a sample-in-answer-out Lab-on-Chip device.

The first efforts in DNA extraction microfluidic modules involved the adaptation of benchtop DNA extraction protocols [41-46] in a microfluidic device. The main challenges faced by these early examples included the need to handle multiple chemical reagents in multistep assays, along with the transfer of reagents between solid and liquid phases. Furthermore, it is worth noting that care needs to be taken on the extraction reagent selection, so that they do not inhibit any subsequent amplification or detection steps [47].

Another very interesting microfluidic implementation involves the utilization of magnetic particles. For example, Karle et al. [48] cultured the bacterium Escherichia coli in a magnetic bead suspension, along with lysis and binding buffers, resulting in the bacterial DNA being extracted and attached on the magnetic bead surfaces (Figure 8). The DNA-carrying beads could then be directed at will within the chip using a rotating permanent magnet. This approach significantly simplifies the designed chip and fluidic handling steps required. One of the most commercially successful implementations of a DNA extraction microfluidic module is found in the GeneXpert MTB/RIF [49]. In this system, the cells of interest are isolated from the sample though filtration, and their DNA is released via sonication. 


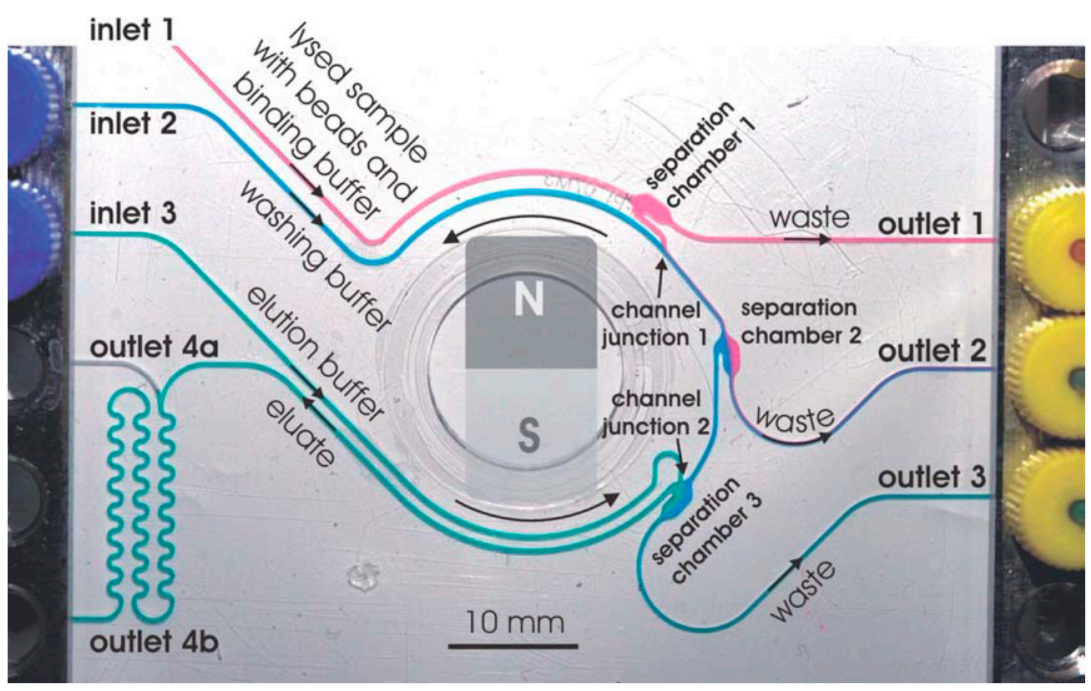

Figure 8. Photograph of magnetic particle assisted DNA extraction chip (Reprinted from Karle et al. [48]. Copyright (2010), with permission from Royal Society of Chemistry).

\subsection{DNA Amplification}

Very often the concentration of the extracted DNA within the sample volume proves to be too low for a biosensing system to detect. As such, it is common to incorporate a DNA amplification step prior to sensing. The first, most common and most frequently used DNA amplification technique is Polymerase Chain Reaction (PCR) [50]. PCR was first developed in 1984 and involves the thermal cycling of the PCR mixture between three thermal zones: Melting (denaturation of the DNA double helix), annealing (attachment of the complementary primer DNA), and extension (polymerase extension of the primer region to form a new double helix copy). Hence, the DNA concentration is doubled after each thermal cycle, resulting in a final concentration of $2^{\mathrm{N}}$ after $\mathrm{N}$ thermal cycles.

This procedure has long been exploited in molecular biology laboratories, using benchtop equipment called thermocyclers. The large thermal mass of the chambers and the samples result in lengthy heating and cooling cycles, leading to DNA amplification times in the order of a couple of hours. To this end, microfluidic devices have been exploited to accelerate this process in a two-fold manner: First by miniaturizing the chambers to accelerate reaction times, and second by reducing both the sample and the device thermal mass, to reduce the heating and cooling times required. Several such devices have been presented in the literature [50], achieving impressive analysis times (in the order of minutes as opposed to hours), and allowing their integration with additional microfluidic modules. The minimization of the heating power consumption has also been pursued [51], following several approaches (i.e., integrated heaters, elaborate temperature control algorithms), allowing the incorporation of such components into portable systems.

This high temperature and thermal cycling requirement has led in parallel to the development of alternative, lower engineering specification amplification protocols, operating with only one constant temperature, i.e., isothermal amplification protocols [52]. Several protocols have been developed, differing in terms of ease of operation and performance. The main techniques involve Helicase-Dependent Amplification (HDA), Strand Displacement Amplification (SDA), Recombinase Polymerase Amplification (RPA), Nucleic Acid Sequence Based Amplification (NASBA), and Loopmediated isothermal amplification (LAMP). Recently, most of the developed isothermal amplification protocols have also been integrated into microfluidic devices, varying in the reaction times achieved and in power consumption [52,53]. A constraint that needs to be considered when exploiting these techniques, as opposed to conventional PCR, is the complexity of the assay design, and the related increased reagent cost. In some of these techniques, 6-8 different primers may be needed for one reaction. Nonetheless, the minimal hardware requirements of these techniques makes them ideal for 
their implementation in paper-based microfluidic devices (Figure 9), particularly suited for use in resource limited settings [54].

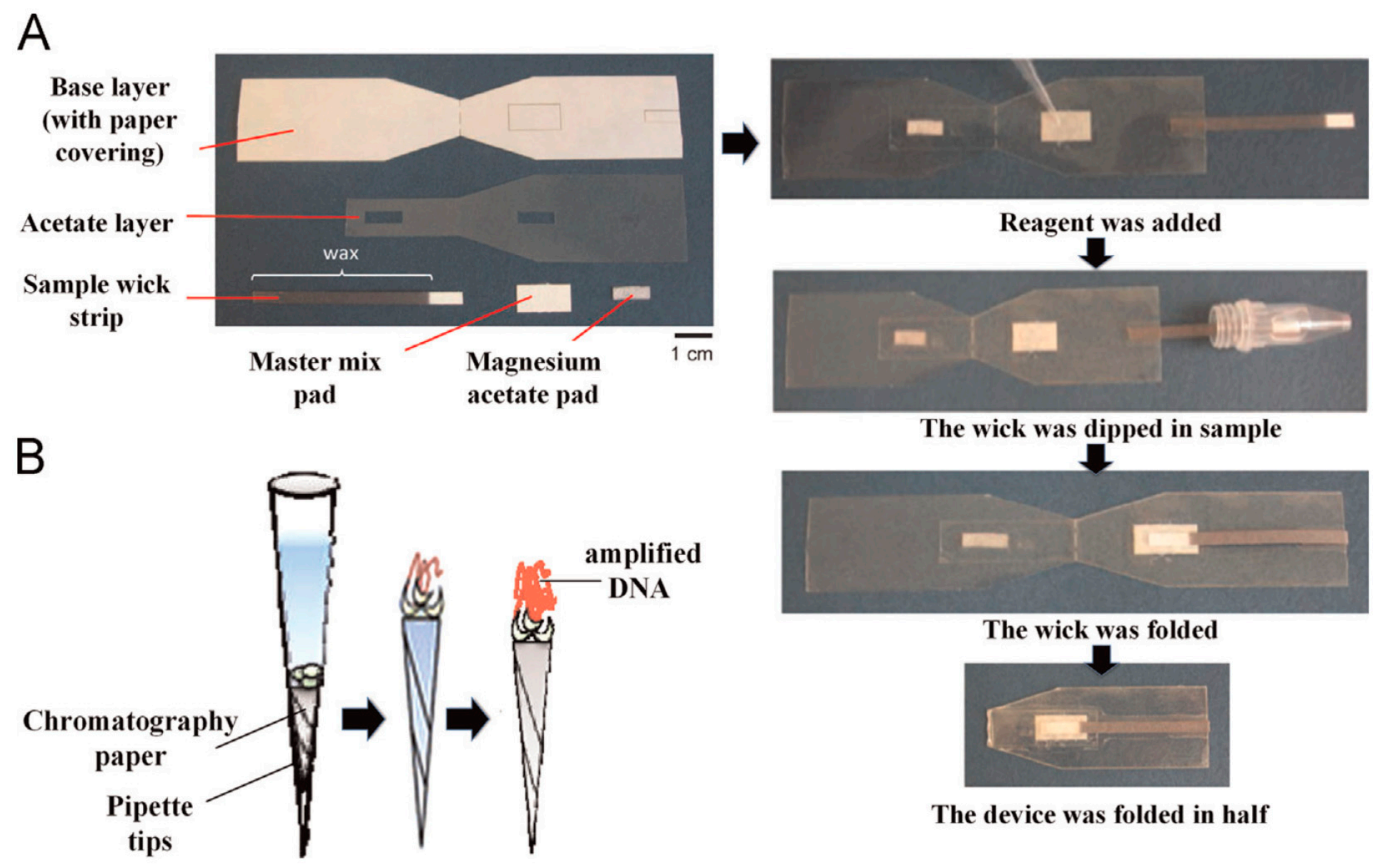

Figure 9. (A) Recombinase Polymerase Amplification (RPA) and (B) Helicase-Dependent Amplification (had) paper-based devices for nucleic acid amplification (Reprinted from Choi et al. [54]. Copyright (2015), with permission from Elsevier).

\section{Higher Integration Platforms}

With the realization of all the previously reported efforts, the true potential of Lab-on-Chip technology can be realized in sample-in-answer-out devices. The whole analytical procedures described earlier (including sample pretreatment, sample manipulation, separation, reaction, and detection), can be integrated into a single chip platform. Over the past years, several partially integrated systems have been presented in literature, with increasing complexity and degree of integration in more recent studies. An in situ electrochemical (EC) detection method in a microfluidic flow-through EC-quantitative PCR (FTEC-qPCR) device was developed, where both the target DNA amplification and subsequent EC detection of the PCR amplicon were performed simultaneously in the same device [55]. An electroactive reporter (methylene blue) was used for in situ EC detection of the PCR amplicon. Woolley et al. demonstrated an integrated microfluidic device, which permitted the direct integration of microfabricated PCR and capillary electrophoresis (CE) components on a single micro-device [56]. The rapid thermal cycling capabilities of microfabricated PCR devices with high-speed DNA separations provided by microfabricated CE chips, was the critical microfluidic addition. A microfabricated device for cell isolation was presented by Wilding and co-workers [57], with the benefit of integrating whole blood sample preparation on-chip for subsequent nucleic acid amplification. White blood cells were isolated from whole blood in silicon-glass microchips using filters, formed by an etched silicon dam spanning the flow chamber. The direct DNA amplification was done using polymerase chain reaction from the white cells isolated on the filters. Papadakis et al. 2018 [58] reported a micro-nano-bio acoustic system for the detection of foodborne pathogens in real samples with a highly integrated microfluidic system. The authors used immuno-magnetic beads to capture cells, and subsequently demonstrate efficient DNA amplification using the Loop Mediated Isothermal Amplification method (LAMP) and acoustic detection in an integrated platform. However, there was still a need to further integrate more of the required detection steps in a single microfluidic chip. Liu et al. presented a highly integrated plastic monolithic device, where PCR amplification, 
DNA hybridization, and a post-hybridization wash have been integrated in a single, low-cost, disposable monolithic device, containing all of the necessary fluidic channels and reservoirs [59]. Very recently, Nguyen et al. developed a unique highly integrated microfluidic device, performing not only the amplification of DNA of Salmonella spp. within $30 \mathrm{~min}$, but also the immediate subsequent measurement of DNA amplicon by the SPR fiber sensor part [60]. The novelty was the integration of a polymerase chain reaction (PCR) microdevice and a surface plasmon resonance (SPR) optical fiber sensor into an inline all-in-one device (Figure 10). The authors proposed that the detection instrument could be further miniaturized by incorporating a miniaturized light source/photodiode.

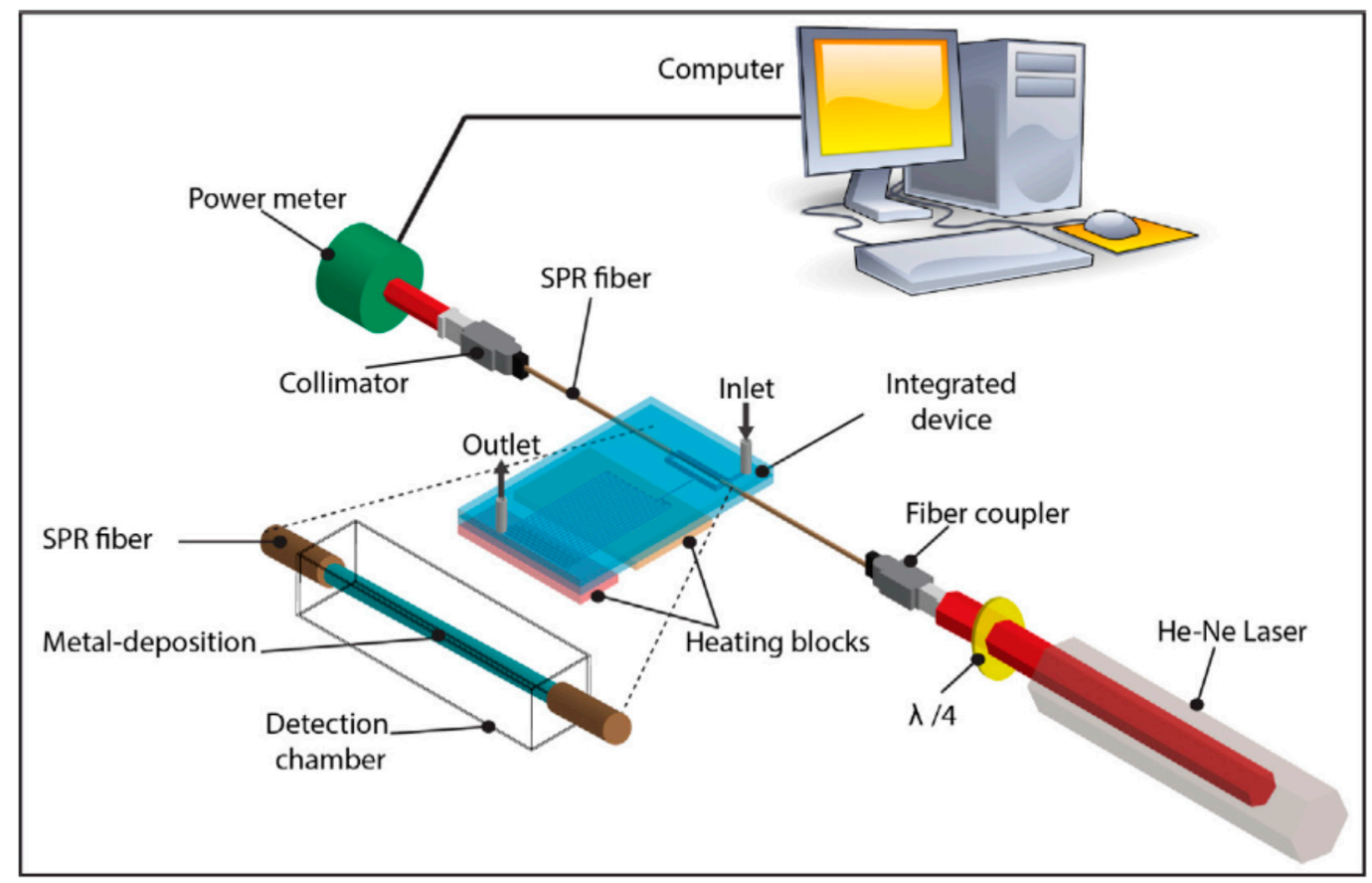

Figure 10. Schematic illustration of DNA amplicon detection (Reprinted from Nguyen et al. [60]. Copyright (2017), with permission from Elsevier).

Another multiplexed integrated label-free DNA detection platform was proposed by including two functional modules, i.e., a multiplexed PCR module for amplification of nucleic acid targets, and a multiplexed silicon nanowire (SiNW) module for sequence determination [61]. The PCR module consisted of a microfluidic PCR chamber and an electrical controller. A control SiNW was implemented to eliminate background interference. The detection module demonstrated a 10-fold change in the magnitude of differential current when the target DNA was injected. The low sample consumption, high sensitivity, and high specificity, rendered it a potential point-of-care (POC) platform to assist doctors in reaching a yes/no decision for infectious diseases.

To eliminate the time-consuming PCR step, Medina-Sánchez et al. reported an ultrasensitive label-free DNA biosensor with fully on-chip integrated rolled-up nanomembrane electrodes, for avian influenza virus subtype H1N1 DNA detection, with an attomolar detection range for miniaturized sensors without amplification. The electrodes were prepared via sequential deposition of strained nanomembranes onto a sacrificial layer, which was then selectively dissolved, resulting in the self-roll-up of the microtubular electrodes [62].

Haber et al. [63] recently integrated on-chip DNA hybridization and real-time PCR using an LSPR-based sensor. They outlined the development of a novel microfluidic sensor for the implementation of qPCR, employing a piezo-electric pumping microsystem. Complementary DNA probes were immobilized onto the surface of nanoprisms on the surface of glass attached via poly-L-lysine linkers. DNA hybridization was then measured using label-free LSPR imaging for 
real-time results (Figure 11). A limit of detection of $5 \mathrm{fg} / \mu \mathrm{L}$ was demonstrated for E. coli DNA (approximately 300 bacteria per $\mathrm{mL}$ ). Detection of target DNA was achieved within 15 min of PCR initiation, which promises the type of rapid diagnosis required for POC devices.

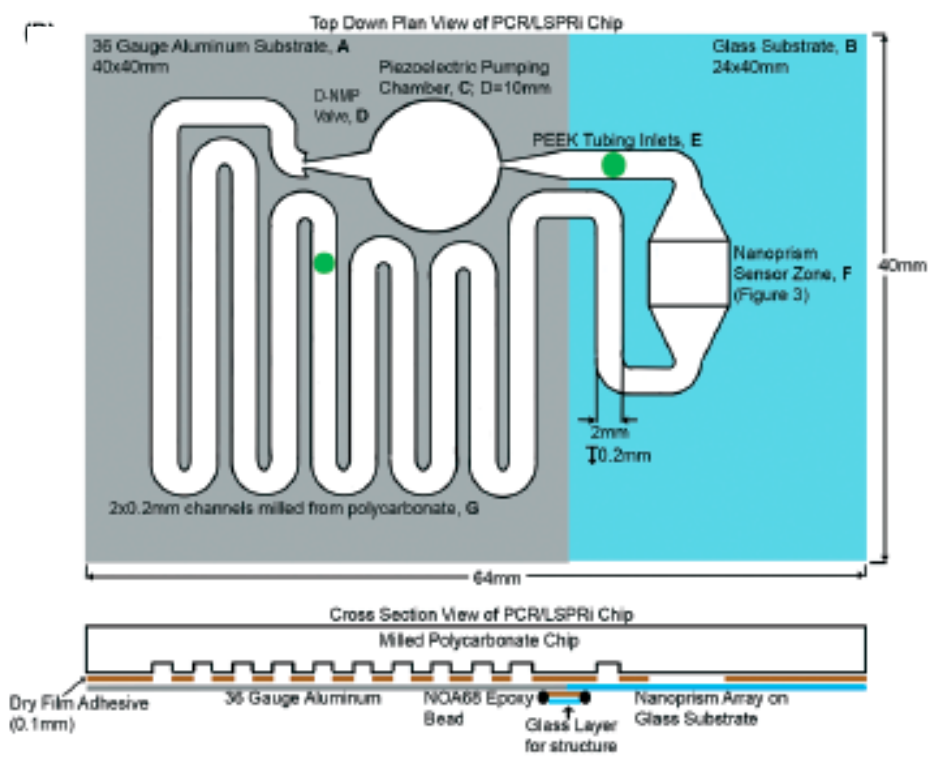

Figure 11. Structural microfluidic channel layout of Polymerase Chain Reaction (PCR) chip (Reprinted from Haberet al. [63]. Copyright (2017), with permission from Royal Society of Chemistry).

Droplet-based microfluidics are also an ideal integration platform for applications requiring high-throughput analysis [64]. These systems offer the unique advantages of automated compartmentalization of reagents in multiple picoliter volume drops, along with the possibility to perform in a programmable way, multiple combinations of reagents rapidly. Many such platforms have been integrated with label-free biosensors. Indicatively, Malic et al. [65] incorporated Surface Plasmon Resonance Imaging (SPRi) DNA sensors, achieving 500 pM LOD. Hsieh et al. [66] employed a molecular beacon fluorescence detection approach achieving $500 \mathrm{fM} \mathrm{LOD,} \mathrm{whilst} \mathrm{Ebrahimi} \mathrm{et} \mathrm{al.} \mathrm{[67]}$ integrated non-Faradaic electrochemical impedance spectroscopy biosensors in a droplet microfluidic platform, reaching aM-scale DNA detection.

\section{Nanopore Technology for Label-Free DNA Sequencing}

Nanopore-based systems are nanofluidic devices for label-free sequencing of DNA molecules, drawing inspiration from the biological nanopores present in cellular membranes [68]. The physical concept can be accurately described as a micro-Coulter counter for DNA bases; where a voltage is applied between the nanopore inlet and outlet, and the polynucleotide bases passing through the pore modulate the ionic current proportionally, allowing the sequential identification of each base in the analyzed strand.

The first nanopore sensor mimicked this natural presence of nanopores in biological membranes (Figure 12), embedding a single $\alpha$-hemolysin protein in a lipid bilayer to exploit its inner diameter compatibility with DNA molecules. Solid state nanopores (e.g., $\mathrm{SiN}_{\mathrm{x}}, \mathrm{SiO}_{2}$ ) soon substituted the biological original protein nanopores, owing to the instability of the supporting lipid bilayer under chemical, electrical, or physical variations. The introduction of solid state nanopores also allowed more versatility in their fabrication, enabling variable but controlled diameters and geometries, even in sub-nanometer resolutions. 


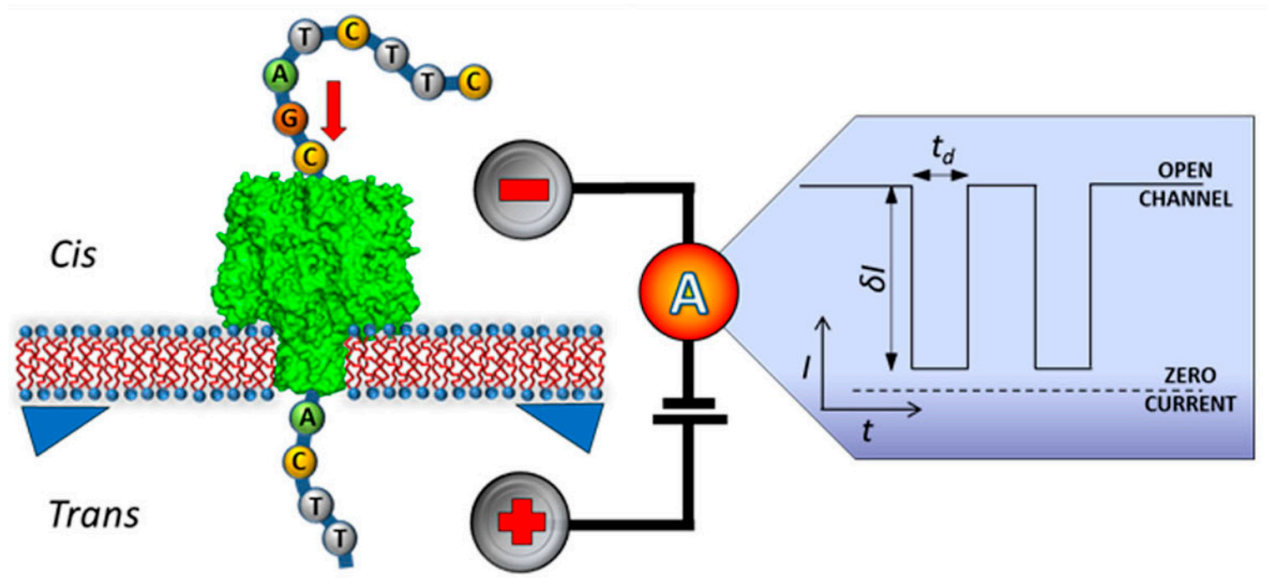

Figure 12. Structural microfluidic channel layout of PCR chip (Reprinted from Kudr et al. [68]. Copyright (2015), with permission from John Wiley and Sons).

This advancement towards solid state nanopores has given rise to a variety of nanofabrication efforts [69] exploiting different material properties, aiming to achieve the optimum nanopore resolution, thickness, and reduction of DNA passage speed through the nanopore. The combination of e-beam lithography with reactive ion etching, focused-ion beam, and helium ion beam methods, have been presented in literature with impressive results. Currently, the prevailing technique lies with transmission electron microscopy (TEM) focused ion beam, allowing real time control of nanopore formation in the order of $2 \mathrm{~nm}$ diameters. Another interesting alternative fabrication technique involves glass capillary nanopores (also known as glass nanopipettes) [70,71]. This approach proves particularly advantageous in terms of stiffness, manufacturability, and cost-effectiveness, with shrinking of the device, making it ideal for DNA translocation studies [72].

The nanofabrication of a complete, high performing nanopore-based DNA sequencing system is currently the main focus of researchers [73,74], with the objective of combining solid state nanopores, sensing nanoelectrodes for the detection of the electrical signal and sample delivery nanofluidics into a rapid and reliable DNA sequencing microchip. The commercial success of Oxford Nanopore Ltd. (see the following paragraph), launching MinION as the first portable commercial label-free sequencer [75], has led researchers to assess its performance in several real-life applications, and to try to identify its current limitations [76-78]. The initial results look very promising in terms of throughput and analysis time, nonetheless, further technological development is required to reduce the error rate to match benchtop equipment performance.

\section{Commercial Systems}

In the commercial arena, one of the most widely used techniques for label-free biosensing of DNA is IonTorrent, now part of Thermo Fisher Scientific, which uses semiconductor technology for DNA sequencing. The process involves the library preparation by DNA fragmentation and attachment to a magnetic bead, where a single fragment is amplified. Beads carrying copies of label-free ssDNA are loaded onto the sequencing chip, where each of the beads is captured in an individual well containing a miniaturized ion-sensitive field-effect transistor (ISFET) $\mathrm{pH}$ sensor. The chip is flooded with a solution containing a single nucleotide type and where a match is present, the nucleotide is incorporated, releasing a hydrogen ion which lowers the $\mathrm{pH}$ of the solution in the well, and is detected by the built-in ISFET. If more than one base is present in succession, the signal gets proportionally higher. Different nucleotide solutions are sequentially introduced onto the chip, enabling the sequence determination. Millions of wells are simultaneously recording nucleotide incorporation, enabling parallel reading and massive scalability $[79,80]$. IonTorrent technology is currently covering multiple applications from targeted DNA sequencing, microRNA sequencing, to bacterial and viral typing [81]. 
Oxford Nanopore Technologies, a spinout from the University of Oxford, brought sequencing technology to its users as a USB powered pocket-sized device called MinION. To start off, a DNA library can be prepared in $10 \mathrm{~min}$, and data can be observed in real time during sequencing. After commercialization of MinION in 2014, the GridION and PromethION systems have been developed, enabling up to 5 and 48 parallel MinION flow cells, respectively [82]. The MinION device has been used to sequence human genome [83], and has been especially useful in monitoring epidemic diseases at remote locations, due to is portability and sequencing speed [84]. The company is currently working on an even smaller portable device, which will be able to perform sequencing whilst connected to a smartphone [82].

In the effort to bring nucleic acid detection to remote locations, QuantuMDx is developing the Q-POC ${ }^{\mathrm{TM}}$, a handheld device compatible with disease specific cartridges [85], capable of sample preparation, DNA extraction, amplification, and detection in 10-20 $\mathrm{min}$, from multiple biological samples [86]. They envision a wide area of applications, ranging from drug resistance analyses for tuberculosis, infectious disease identification, such as STIs and HPV, to metabolism genotyping to identify the optimal warfarin dosage [87]. The company is developing two detection approaches [88]: An optical based strategy using fluorescent markers and an electrochemical one, based on label-free nanowire field effect transistors [89]. One of their goals is to create a world-wide map to monitor pathogen evolution, in the effort to prevent global outbreaks [86]. To achieve this, they are aiming to use nanowire FETs to sequence pathogens DNA in a portable device [89]. However, to the best of our knowledge, the Q-POC ${ }^{\mathrm{TM}}$ device, which is planned to be launched in 2018, uses fluorescence detection [86].

Another company trying to reach the diagnostic market is Atlas Genetics, a spinout from the University of Bath, which offers their CE-marked io ${ }^{\circledR}$ system for detection of STIs and other infections. The io ${ }^{\circledR}$ instrument is a benchtop device, in which a single-use cartridge is inserted, and the result is obtained within $30 \mathrm{~min}$. First, the sample is introduced into the cartridge, where DNA is extracted and amplified via PCR [90]. The detection chamber includes target complementary probes, linked to a ferrocene tag and a double strand specific nuclease [91]. When a label-free target DNA hybridizes with a detection probe, nuclease cleaves off the ferrocene tag, which is detected electrochemically, using differential pulse voltammetry [92]. Including multiple detection chambers in a single cartridge, and engineering ferrocene labels and their electrochemical properties [93], grants the io ${ }^{\circledR}$ system a high capacity for multiplexing. They have published multiple studies using clinical material for diagnosis of pathogenic Candida species [94,95], Chlamydia trachomatis [96], and Trichomonas vaginalis [97].

Recently DNAe, a spin-out from Imperial College London, presented a semiconductor sequencing based benchtop device called $\mathrm{LiDia}{ }^{\mathrm{TM}}$, which can accurately detect pathogen DNA and identify from bloodstream infections to antimicrobial resistance. During the process, the blood sample is introduced into a disposable cartridge and loaded to the reader. Target extraction, concentration, and isolation, along with genomic analysis on a chip is performed in a single cartridge [98]. The amplification reaction occurs on the chip integrated with embedded heaters and ISFETs. As specific primers recognize the label-free target DNA, the amplification reaction initiates. With each nucleotide being incorporated to an amplicon, a proton is released, lowering the $\mathrm{pH}$ in the solution. Therefore, amplification reaction is detected in real time by the ISFET [99]. DNAe are currently testing the device with clinical samples with a plan for CE application in 2018. One of their main applications is detection of sepsis, where their device can provide information about the appropriate antimicrobial treatment within $3 \mathrm{~h}$ [98].

\section{Conclusions and Future Outlook}

In this article, we reviewed recent technological progress in the field of microfluidic-assisted label-free DNA biosensing devices. We mainly focused on label-free highly integrated biosensor devices, which are suitable for point-of-site detection, such as medical diagnostics, biological research, environmental monitoring, and food analysis. Optical, electrochemical, mass-based label-free biosensing approaches are currently being pursued for microfluidic integration, each featuring 
particular advantages and disadvantages. Mass-based methods can provide very efficient detection for heavier molecules, nonetheless, they can prove less competitive for smaller molecules, such as short chain oligonucleotides. On the other hand, optical approaches can provide very low-limits of detection even for very small molecules; however, they suffer from their elaborate instrumentation requirement in terms of platform miniaturization. Electrochemical biosensors offer the advantage of combined low limits of detection and minimal, low-power instrumentation requirements. All sample preparation microfluidic modules enabling a sample-in-answer-out system (i.e., cell-isolation, DNA extraction, DNA amplification), have been individually demonstrated in the literature; nonetheless, very few efforts for multiple module integration have been reported so far. Multiplexed DNA amplification modules, droplet-based microfluidics, and nanopore-assisted sequencing, clearly indicate the technical feasibility of high-throughput and high specification portable systems in the future. Currently via nanopore technology, it is possible to have DNA sequencing at the point-of-need, at a throughput of 10-20 G bases per $48 \mathrm{~h}$. Whilst such a sequencing throughput is impressive, there are numerous diagnostic applications where full genome sequencing is not required. In such cases, microfluidic platforms offering sample-in-answer-out operations, with time to result of a few minutes, may prove more practical in real-life practice, both for Point-of-Need use in Centralized healthcare systems and for low-resource settings.

Building on more mature technologies in microfluidic DNA systems, several commercial efforts are already promising to launch in the immediate future sample-in-answer-out systems, with specific medical diagnostic applications. A major challenge to be overcome pertains to the cost-effective integration of highly sensitive biosensors in portable devices, or even in equipment-free systems. At the moment, a seamless mass-manufacturing approach for integration of all the required components is not commercially available, with each diagnostic company pursuing their own strategy. Moreover, the exploitation of sensing approaches requiring elaborate or expensive instrumentation can present obstacles in portability, along with the large power requirements associated with heating on modules incorporating DNA amplification. With most practical applications demanding the quantification of multiple DNA strands simultaneously, both assays and devices allowing multiplexed detection need to be developed. Finally, device development should be carried out based on real physiological samples early on, assuring device compliance with international regulatory frameworks and biomedical device standards.

Author Contributions: D.M. and P.E. conceived, structured, and edited the paper. D.M. wrote Section 1, Section 3 , Section 5. G.D. wrote Section 4, Section 7 and was responsible for the overall paper formatting. J.R. wrote Section 2, U.Z. Section 6, and S.P. performed the literature review for Section 2.

Funding: The authors wish to acknowledge the financial support of eFUTURES EPSRC (EP/L025450/1), British Council (Newton Fund Institutional Links, UK-Turkey, 336872), The Royal Society (RSG $\backslash$ R1 $\backslash 180260$ ), and the Rosetrees Trust (A1607).

Conflicts of Interest: The authors declare no conflict of interest.

\section{References}

1. Lafleur, J.P.; Jönsson, A.; Senkbeil, S.; Kutter, J.P. Recent advances in lab-on-a-chip for biosensing applications. Biosens. Bioelectron. 2016, 76, 213-233. [CrossRef] [PubMed]

2. Manz, A.; Graber, N.; Widmer, H.M. Miniaturized total chemical analysis systems: A novel concept for chemical sensing. Sens. Actuators B Chem. 1990, 1, 244-248. [CrossRef]

3. Huang, R.; He, N.; Li, Z. Recent progresses in DNA nanostructure-based biosensors for detection of tumor markers. Biosens. Bioelectron. 2018, 109, 27-34. [CrossRef] [PubMed]

4. Bizid, S.; Blili, S.; Mlika, R.; Haj Said, A.; Korri-Youssoufi, H. Direct E-DNA sensor of Mycobacterium tuberculosis mutant strain based on new nanocomposite transducer (Fc-ac-OMPA/MWCNTs). Talanta 2018, 184, 475-483. [CrossRef] [PubMed]

5. Guijt, R.M.; Manz, A. Miniaturised Total Chemical-Analysis Systems ( $\mu$ TAS) that Periodically Convert Chemical into Electronic Information. Sens. Actuators B Chem. 2018, 273, 1334-1345. [CrossRef] 
6. Sandipan, R.; Gunjan, M.; Sanjeeva, S. Label-free detection techniques for protein microarrays: Prospects, merits and challenges. Proteomics 2010, 10, 731-748.

7. Zanchetta, G.; Lanfranco, R.; Giavazzi, F.; Bellini, T.; Buscaglia, M. Emerging applications of label-free optical biosensors. Nanophotonics 2017, 6, 627-645. [CrossRef]

8. Luka, G.; Ahmadi, A.; Najjaran, H.; Alocilja, E.; DeRosa, M.; Wolthers, K.; Malki, A.; Aziz, H.; Althani, A.; Hoorfar, M. Microfluidics integrated biosensors: A leading technology towards lab-on-a-chip and sensing applications. Sensors 2015, 15, 30011-30031. [CrossRef] [PubMed]

9. Dincer, C.; Kling, A.; Chatelle, C.; Armbrecht, L.; Kieninger, J.; Weber, W.; Urban, G.A. Designed miniaturization of microfluidic biosensor platforms using the stop-flow technique. Analyst 2016, 141, 6073-6079. [CrossRef] [PubMed]

10. Kartanas, T.; Ostanin, V.; Challa, P.K.; Daly, R.; Charmet, J.; Knowles, T.P.J. Enhanced Quality Factor Label-free Biosensing with Micro-Cantilevers Integrated into Microfluidic Systems. Anal. Chem. 2017, 89, 11929-11936. [CrossRef] [PubMed]

11. Fan, X.; White, I.M.; Shopova, S.I.; Zhu, H.; Suter, J.D.; Sun, Y. Sensitive optical biosensors for unlabeled targets: A review. Anal. Chim. Acta 2008, 620, 8-26. [CrossRef] [PubMed]

12. Mukherji, S.; Punjabi, N. Label-Free Integrated Optical Biosensors for Multiplexed Analysis. J. Indian Inst. Sci. 2012, 92, 253-294.

13. Pires, N.M.M.; Dong, T.; Hanke, U.; Hoivik, N. Recent developments in optical detection technologies in lab-on-a-chip devices for biosensing applications. Sensors 2014, 14, 15458-15479. [CrossRef] [PubMed]

14. Liedberg, B.; Nylander, C.; Lunström, I. Surface plasmon resonance for gas detection and biosensing. Sens. Actuators 1983, 4, 299-304. [CrossRef]

15. Yuan, P.-X.; Deng, S.Y.; Zheng, C.Y.; Cosnier, S.; Shan, D. In situ formed copper nanoparticles templated by TdT-mediated DNA for enhanced SPR sensor-based DNA assay. Biosens. Bioelectron. 2017, 97, 1-7. [CrossRef] [PubMed]

16. Kurita, R.; Yanagisawa, H.; Yoshioka, K.; Niwa, O. On-chip sequence-specific immunochemical epigenomic analysis utilizing outward-turned cytosine in a DNA bulge with handheld surface plasmon resonance equipment. Anal. Chem. 2015, 87, 11581-11586. [CrossRef] [PubMed]

17. Hammond, J.L.; Bhalla, N.; Rafiee, S.D.; Estrela, P. Localized surface plasmon resonance as a biosensing platform for developing countries. Biosensors 2014, 4, 172-188. [CrossRef] [PubMed]

18. Gavela, A.F.; Grajales García, D.; Ramirez, J.C.; Lechuga, L.M. Last Advances in Silicon-Based Optical Biosensors. Sensors 2016, 16, 285. [CrossRef] [PubMed]

19. Song, B.; Zhang, H.; Liu, B.; Lin, W.; Wu, J. Label-free in-situ real-time DNA hybridization kinetics detection employing microfiber-assisted Mach-Zehnder interferometer. Biosens. Bioelectron. 2016, 81, 151-158. [CrossRef] [PubMed]

20. Kussrow, A.; Enders, C.S.; Bornhop, D.J. Interferometric Methods for Label-Free Molecular Interaction Studies. Anal. Chem. 2011, 84, 779-792. [CrossRef] [PubMed]

21. Jahn, I.J.; Žukovskaja, O.; Zheng, X.S.; Weber, K.; Bocklitz, T.W.; Cialla-May, D.; Popp, J. Surface-enhanced Raman spectroscopy and microfluidic platforms: Challenges, solutions and potential applications. Analyst 2017, 142, 1022-1047. [CrossRef] [PubMed]

22. Strelau, K.K.; Kretschmer, R.; Möller, R.; Fritzsche, W.; Popp, J. SERS as tool for the analysis of DNA-chips in a microfluidic platform. Anal. Bioanal. Chem. 2010, 396, 1381-1384. [CrossRef] [PubMed]

23. Qi, J.; Zeng, J.; Zhao, F.; Lin, S.H.; Raja, B.; Strych, U.; Willson, R.C.; Shih, W.C. Label-free, in situ SERS monitoring of individual DNA hybridization in microfluidics. Nanoscale 2014, 6, 8521-8526. [CrossRef] [PubMed]

24. Novara, C.; Chiadò, A.; Paccotti, N.; Catuogno, S.; Esposito, C.L.; Condorelli, G.; De Franciscis, V.; Geobaldo, F.; Rivolo, P.; Giorgis, F. SERS-active metal-dielectric nanostructures integrated in microfluidic devices for label-free quantitative detection of miRNA. Faraday Discuss. 2017, 205, 271-289. [CrossRef] [PubMed]

25. Hammond, J.L.; Formisano, N.; Estrela, P.; Carrara, S.; Tkac, J. Electrochemical biosensors and nanobiosensors. Essays Biochem. 2016, 60, 69-80. [CrossRef] [PubMed]

26. Rackus, D.G.; Shamsi, M.H.; Wheeler, A.R. Electrochemistry, biosensors and microfluidics: A convergence of fields. Chem. Soc. Rev. 2015, 44, 5320-5340. [CrossRef] [PubMed] 
27. Choi, K.; Kim, J.Y.; Ahn, J.H.; Choi, J.M.; Im, M.; Choi, Y.K. Integration of field effect transistor-based biosensors with a digital microfluidic device for a lab-on-a-chip application. Lab Chip 2012, 12, 1533-1539. [CrossRef] [PubMed]

28. Xu, G.; Abbott, J.; Qin, L.; Yeung, K.Y.; Song, Y.; Yoon, H.; Kong, J.; Ham, D. Electrophoretic and field-effect graphene for all-electrical DNA array technology. Nat. Commun. 2014, 5, 4866. [CrossRef] [PubMed]

29. Ben-Yoav, H.; Dykstra, P.H.; Gordonov, T.; Bentley, W.E.; Ghodssi, R. A microfluidic-based electrochemical biochip for label-free DNA hybridization analysis. Biosens. Bioelectron. 2012, 38, 114-120. [CrossRef] [PubMed]

30. Jolly, P.; Batistuti, M.R.; Miodek, A.; Zhurauski, P.; Mulato, M.; Lindsay, M.A.; Estrela, P. A simple and highly sensitive electrochemical platform for detection of MicroRNAs. In Proceedings of the IEEE SENSORS, Busan, Korea, 1-4 November 2015; pp. 803-806.

31. Wu, C.-C.; Huang, W.-C.; Hu, C.-C. An ultrasensitive label-free electrochemical impedimetric DNA biosensing chip integrated with a DC-biased AC electroosmotic vortex. Sens. Actuators B Chem. 2015, 209, 61-68. [CrossRef]

32. Hong, S.-R.; Jeong, H.-D.; Hong, S. QCM DNA biosensor for the diagnosis of a fish pathogenic virus VHSV. Talanta 2010, 82, 899-903. [CrossRef] [PubMed]

33. García-Martinez, G.; Bustabad, E.A.; Perrot, H.; Gabrielli, C.; Bucur, B.; Lazerges, M.; Rose, D.; Rodriguez-Pardo, L.; Fariña, J.; Compère, C.; Vives, A.A. Development of a mass sensitive quartz crystal microbalance (QCM)-based DNA biosensor using a $50 \mathrm{MHz}$ electronic oscillator circuit. Sensors 2011, 11, 7656-7664. [CrossRef] [PubMed]

34. Gronewold, T.M.; Baumgartner, A.; Quandt, E.; Famulok, M. Discrimination of single mutations in cancer-related gene fragments with a surface acoustic wave sensor. Anal. Chem. 2006, 78, 4865-4871. [CrossRef] [PubMed]

35. Liu, X.; Wang, J.-Y.; Mao, X.-B.; Ning, Y.; Zhang, G.-J. Single-shot analytical assay based on grapheneoxide-modified surface acoustic wave biosensor for detection of single-nucleotide polymorphisms. Anal. Chem. 2015, 87, 9352-9359. [CrossRef] [PubMed]

36. Go, D.B.; Atashbar, M.Z.; Ramshani, Z.; Chang, H.C. Surface acoustic wave devices for chemical sensing and microfluidics: A review and perspective. Anal. Methods 2017, 9, 4112-4134. [CrossRef] [PubMed]

37. Zhang, Y.; Yang, F.; Sun, Z.; Li, Y.T.; Zhang, G.J. A surface acoustic wave biosensor synergizing DNA-mediated in situ silver nanoparticle growth for a highly specific and signal-amplified nucleic acid assay. Analyst 2017, 142, 3468-3476. [CrossRef] [PubMed]

38. Ayoib, A.; Hashim, U.; Gopinath, S.C.B.; Md Arshad, M.K. DNA extraction on bio-chip: History and preeminence over conventional and solid-phase extraction methods. Appl. Microbiol. Biotechnol. 2017, 101, 8077-8088. [CrossRef] [PubMed]

39. Tan, S.C.; Yiap, B.C. DNA, RNA, and protein extraction: The past and the present. BioMed Res. Int. 2009, 2009, 574398.

40. Ali, N.; Rampazzo, R.C.P.; Costa, A.D.T.; Krieger, M.A. Current nucleic acid extraction methods and their implications to point-of-care diagnostics. BioMed Res. Int. 2017, 2017, 9306564. [CrossRef] [PubMed]

41. Breadmore, M.C.; Wolfe, K.A.; Arcibal, I.G.; Leung, W.K.; Dickson, D.; Giordano, B.C.; Power, M.E.; Ferrance, J.P.; Feldman, S.H.; Norris, P.M.; et al. Microchip-based purification of DNA from biological samples. Anal. Chem. 2003, 75, 1880-1886. [CrossRef] [PubMed]

42. Cady, N.C.; Stelick, S.; Batt, C.A. Nucleic acid purification using microfabricated silicon structures. Biosens. Bioelectron. 2003, 19, 59-66. [CrossRef]

43. Chen, X.; Cui, D.F.; Sun, J.H.; Zhang, L.L.; Li, H. Microdevice-based DNA extraction method using green reagent. Key Eng. Mater. 2013, 562-565, 1111-1115. [CrossRef]

44. Chen, X.; Cui, D.-F.; Liu, C.-C. High purity DNA extraction with a SPE microfluidic chip using KI as the binding salt. Chin. Chem. Lett. 2006, 17, 1101-1104.

45. Chung, Y.-C.; Jan, M.S.; Lin, Y.C.; Lin, J.H.; Cheng, W.C.; Fan, C.Y. Microfluidic chip for high efficiency DNA extraction. Lab Chip 2004, 4, 141-147. [CrossRef] [PubMed]

46. Wolfe, K.A.; Breadmore, M.C.; Ferrance, J.P.; Power, M.E.; Conroy, J.F.; Norris, P.M.; Landers, J.P. Toward a microchip-based solid-phase extraction method for isolation of nucleic acids. Electrophoresis 2002, 23, 727-733. [CrossRef] 
47. Wu, J.; Kodzius, R.; Cao, W. Extraction, amplification and detection of DNA in microfluidic chip-based assays. Microchim. Acta 2014, 181, 1611-1631. [CrossRef]

48. Karle, M.; Miwa, J.; Czilwik, G.; Auwärter, V.; Roth, G.; Zengerle, R.; von Stetten, F. Continuous microfluidic DNA extraction using phase-transfer magnetophoresis. Lab Chip 2010, 10, 3284-3290. [CrossRef] [PubMed]

49. Boehme, C.C.; Nabeta, P.; Hillemann, D.; Nicol, M.P.; Shenai, S.; Krapp, F.; Allen, J.; Tahirli, R.; Blakemore, R.; Rustomjee, R.; et al. Rapid molecular detection of tuberculosis and rifampin resistance. N. Engl. J. Med. 2010, 363, 1005-1015. [CrossRef] [PubMed]

50. Zhang, Y.; Ozdemir, P. Microfluidic DNA amplification-A review. Anal. Chim. Acta 2009, 638, 115-125. [CrossRef] [PubMed]

51. Capretto, L.; Cheng, W.; Hill, M.; Zhang, X. Microfluidics Technologies and Applications. Top. Curr. Chem. 2011, 304, 27-68. [PubMed]

52. Giuffrida, M.C.; Spoto, G. Integration of isothermal amplification methods in microfluidic devices: Recent advances. Biosens. Bioelectron. 2017, 90, 174-186. [CrossRef] [PubMed]

53. Tsaloglou, M.-N.; Nemiroski, A.; Camci-Unal, G.; Christodouleas, D.C.; Murray, L.P.; Connelly, J.T.; Whitesides, G.M. Handheld isothermal amplification and electrochemical detection of DNA in resourcelimited settings. Anal. Biochem. 2018, 543, 116-121. [CrossRef] [PubMed]

54. Choi, J.R.; Tang, R.; Wang, S.; Wan Abas, W.A.; Pingguan-Murphy, B.; Xu, F. Paper-based sample-to-answer molecular diagnostic platform for point-of-care diagnostics. Biosens. Bioelectron. 2015, 74, 427-439. [CrossRef] [PubMed]

55. Fang, T.H.; Ramalingam, N.; Xian-Dui, D.; Ngin, T.S.; Xianting, Z.; Lai Kuan, A.T.; Peng Huat, E.Y.; Hai-Qing, G. Real-time PCR microfluidic devices with concurrent electrochemical detection. Biosens. Bioelectron. 2009, 24, 2131-2136. [CrossRef] [PubMed]

56. Woolley, A.T.; Hadley, D.; Landre, P.; de Mello, A.J.; Mathies, R.A.; Northrup, M.A. Functional integration of PCR amplification and capillary electrophoresis in a microfabricated DNA analysis device. Anal. Chem. 1996, 68, 4081-4086. [CrossRef] [PubMed]

57. Wilding, P.; Kricka, L.J.; Cheng, J.; Hvichia, G.; Shoffner, M.A.; Fortina, P. Integrated cell isolation and polymerase chain reaction analysis using silicon microfilter chambers. Anal. Biochem. 1998, 257, 95-100. [CrossRef] [PubMed]

58. Papadakis, G.; Murasova, P.; Hamiot, A.; Tsougeni, K.; Kaprou, G.; Eck, M.; Rabus, D.; Bilkova, Z.; Dupuy, B.; Jobst, G.; et al. Micro-nano-bio acoustic system for the detection of foodborne pathogens in real samples. Biosens. Bioelectron. 2018, 111, 52-58. [CrossRef] [PubMed]

59. Liu, Y.; Rauch, C.B.; Stevens, R.L.; Lenigk, R.; Yang, J.; Rhine, D.B.; Grodzinski, P. DNA amplification and hybridization assays in integrated plastic monolithic devices. Anal. Chem. 2002, 74, 3063-3070. [CrossRef] [PubMed]

60. Nguyen, T.T.; Trinh, K.L.; Yoon, W.J.; Lee, N.Y.; Ju, H. Integration of a microfluidic polymerase chain reaction device and surface plasmon resonance fiber sensor into an inline all-in-one platform for pathogenic bacteria detection. Sens. Actuators B Chem. 2017, 242, 1-8. [CrossRef]

61. Kao, L.T.-H.; Shankar, L.; Kang, T.G.; Zhang, G.; Tay, G.K.; Rafei, S.R.; Lee, C.W. Multiplexed detection and differentiation of the DNA strains for influenza A (H1N1 2009) using a silicon-based microfluidic system. Biosens. Bioelectron. 2011, 26, 2006-2011. [CrossRef] [PubMed]

62. Medina-Sánchez, M.; Ibarlucea, B.; Pérez, N.; Karnaushenko, D.D.; Weiz, S.M.; Baraban, L.; Cuniberti, G.; Schmidt, O.G. High-performance three-dimensional tubular nanomembrane sensor for DNA detection. Nano Lett. 2016, 16, 4288-4296. [CrossRef] [PubMed]

63. Haber, J.; Gascoyne, P.; Sokolov, K. Rapid real-time recirculating PCR using localized surface plasmon resonance (LSPR) and piezo-electric pumping. Lab Chip 2017, 17, 2821-2830. [CrossRef] [PubMed]

64. Dak, P.; Ebrahimi, A.; Swaminathan, V.; Duarte-Guevara, C.; Bashir, R.; Alam, M.A. Droplet-based biosensing for lab-on-a-chip, open microfluidics platforms. Biosensors 2016, 6, 14. [CrossRef] [PubMed]

65. Malic, L.; Veres, T.; Tabrizian, M. Nanostructured digital microfluidics for enhanced surface plasmon resonance imaging. Biosens. Bioelectron. 2011, 26, 2053-2059. [CrossRef] [PubMed]

66. Hsieh, A.T.-H.; Pan, P.J.-H.; Lee, A.P. Rapid label-free DNA analysis in picoliter microfluidic droplets using FRET probes. Microfluid. Nanofluid. 2009, 6, 391. [CrossRef] 
67. Ebrahimi, A.; Dak, P.; Salm, E.; Dash, S.; Garimella, S.V.; Bashir, R.; Alam, M.A. Nanotextured superhydrophobic electrodes enable detection of attomolar-scale DNA concentration within a droplet by non-faradaic impedance spectroscopy. Lab Chip 2013, 13, 4248-4256. [CrossRef] [PubMed]

68. Kudr, J.; Skalickova, S.; Nejdl, L.; Moulick, A.; Ruttkay-Nedecky, B.; Adam, V.; Kizek, R. Fabrication of solid-state nanopores and its perspectives. Electrophoresis 2015, 36, 2367-2379. [CrossRef] [PubMed]

69. Zhang, Y.; Reisner, W. Fabrication and characterization of nanopore-interfaced nanochannel devices. Nanotechnology 2015, 26, 455301. [CrossRef] [PubMed]

70. Freedman, K.J.; Otto, L.M.; Ivanov, A.P.; Barik, A.; Oh, S.H.; Edel, J.B. Nanopore sensing at ultra-low concentrations using single-molecule dielectrophoretic trapping. Nat. Commun. 2016, 7, 10217. [CrossRef] [PubMed]

71. Sze, J.Y.Y.; Kumar, S.; Ivanov, A.P.; Oh, S.H.; Edel, J.B. Fine tuning of nanopipettes using atomic layer deposition for single molecule sensing. Analyst 2015, 140, 4828-4834. [CrossRef] [PubMed]

72. Xu, X.; Li, C.; Zhou, Y.; Jin, Y. Controllable Shrinking of Glass Capillary Nanopores Down to sub-10 nm by Wet-Chemical Silanization for Signal-Enhanced DNA Translocation. ACS Sens. 2017, 2, 1452-1457. [CrossRef] [PubMed]

73. Briggs, K.; Madejski, G.; Magill, M.; Kastritis, K.; de Haan, H.W.; McGrath, J.L.; Tabard-Cossa, V. DNA translocations through nanopores under nanoscale preconfinement. Nano Lett. 2017, 18, 660-668. [CrossRef] [PubMed]

74. Tahvildari, R.; Beamish, E.; Tabard-Cossa, V.; Godin, M. Integrating nanopore sensors within microfluidic channel arrays using controlled breakdown. Lab Chip 2015, 15, 1407-1411. [CrossRef] [PubMed]

75. Eisenstein, M. Oxford Nanopore announcement sets sequencing sector abuzz. Nat. Biotechnol. 2012, 30, 295-296. [CrossRef] [PubMed]

76. Laver, T.; Harrison, J.; O’Neill, P.A.; Moore, K.; Farbos, A.; Paszkiewicz, K.; Studholme, D.J. Assessing the performance of the oxford nanopore technologies minion. Biomol. Detect. Quantif. 2015, 3, 1-8. [CrossRef] [PubMed]

77. Lemon, J.K.; Khil, P.P.; Frank, K.M.; Dekker, J.P. Rapid nanopore sequencing of plasmids and resistance gene detection in clinical isolates. J. Clin. Microbiol. 2017, 55, 3530-3543. [CrossRef] [PubMed]

78. Mikheyev, A.S.; Tin, M.M. A first look at the Oxford Nanopore MinION sequencer. Mol. Ecol. Resour. 2014, 14, 1097-1102. [CrossRef] [PubMed]

79. Rothberg, J.M.; Hinz, W.; Rearick, T.M.; Schultz, J.; Mileski, W.; Davey, M.; Leamon, J.H.; Johnson, K.; Milgrew, M.J.; Edwards, M.; Hoon, J.; et al. An integrated semiconductor device enabling non-optical genome sequencing. Nature 2011, 475, 348-352. [CrossRef] [PubMed]

80. Ion Torrent ${ }^{\mathrm{TM}}$ Next-Gen Sequencing Technology. Available online: https://www.youtube.com/watch?v= WYBzbxIfuKs (accessed on 31 July 2018).

81. Ion Torrent. Available online: https://www.thermofisher.com/uk/en/home/brands/ion-torrent.html.html (accessed on 2 November 2017).

82. Oxford Nanopore Technologies, Company History. Available online: https://nanoporetech.com/about-us/ history (accessed on 2 November 2017).

83. Jain, M.; Koren, S.; Miga, K.H.; Quick, J.; Rand, A.C.; Sasani, T.A.; Tyson, J.R.; Beggs, A.D.; Dilthey, A.T.; Fiddes, I.T.; et al. Nanopore sequencing and assembly of a human genome with ultra-long reads. Nat. Biotechnol. 2018, 36, 338-345. [CrossRef] [PubMed]

84. Quick, J.; Loman, N.J.; Duraffour, S.; Simpson, J.T.; Severi, E.; Cowley, L.; Bore, J.A.; Koundouno, R.; Dudas, G.; Mikhail, A.; et al. Real-time, portable genome sequencing for Ebola surveillance. Nature 2016, 530, 228-232. [CrossRef] [PubMed]

85. Vu, C.L.; Chan, J.; Todaro, M.; Skafidas, S.; Kwan, P. Point-of-care molecular diagnostic devices: An overview. Pharmacogenomics 2015, 16, 1399-1409. [CrossRef] [PubMed]

86. QuantuMDx, Q-POCTM. Available online: http://quantumdx.com/systems-o/q-poc-2 (accessed on 2 November 2017).

87. QuantuMDx, Applications. Available online: http:/ / quantumdx.com/applications (accessed on 2 November 2017).

88. Burn, J. Company profile: QuantuMDx group limited. Pharmacogenomics 2013, 14, 1011-1015. [CrossRef] [PubMed] 
89. Anscombe, N. Unravelling DNA. Electro Optics. 2016. Available online: https:/ /www.electrooptics.com/ feature/unravelling-dna (accessed on 2 November 2017).

90. Atlas Genetics, io®System. Available online: http://www.atlasgenetics.com/solutions/systems.html (accessed on 30 July 2018).

91. Edwards, T.R.K.; Mullarkey, T.C.E.; NealeJay, K.D.; Taylor, J.K.; Arlett, B. Fluidic Cartridge for Nucleic Acid Amplification and Detection. U.S. Patent 9,816,135, 14 November 2017.

92. Hillier, S.C.; Flower, S.E.; Frost, C.G.; Jenkins, A.T.A.; Keay, R.; Braven, H. An electrochemical gene detection assay utilising $\mathrm{T} 7$ exonuclease activity on complementary probe-target oligonucleotide sequences. Electrochem. Commun. 2004, 6, 1227-1232. [CrossRef]

93. Marsh, B.J.; Hampton, L.; Goggins, S.; Frost, C.G. Fine-tuning of ferrocene redox potentials towards multiplex DNA detection. New J. Chem. 2014, 38, 5260-5263. [CrossRef]

94. Muir, A.; Jenkins, A.T.; Forrest, G.; Clarkson, J.; Wheals, A. Rapid electrochemical identification of pathogenic Candida species. J. Med. Microbiol. 2009, 58, 1182-1189. [CrossRef] [PubMed]

95. Muir, A.; Forrest, G.; Clarkson, J.; Wheals, A. Detection of Candida albicans DNA from blood samples using a novel electrochemical assay. J. Med. Microbiol. 2011, 60, 467-471. [CrossRef] [PubMed]

96. Pearce, D.M.; Shenton, D.P.; Holden, J.; Gaydos, C.A. Evaluation of a novel electrochemical detection method for Chlamydia trachomatis: Application for point-of-care diagnostics. IEEE Trans. Biomed. Eng. 2011, 58, 755-758. [CrossRef] [PubMed]

97. Pearce, D.M.; Styles, D.N.; Hardick, J.P.; Gaydos, C.A. A new rapid molecular point-of-care assay for Trichomonas vaginalis: Preliminary performance data. Sex. Transm. Infect. 2013, 89, 495-497. [CrossRef] [PubMed]

98. DNAe. Available online: https:/ / www.dnae.com/ (accessed on 2 November 2017).

99. Toumazou, C.; Shepherd, L.M.; Reed, S.C.; Chen, G.I.; Patel, A.; Garner, D.M.; Wang, C.J.; Ou, C.P.; Amin-Desai, K.; Athanasiou, P.; et al. Simultaneous DNA amplification and detection using a pH-sensing semiconductor system. Nat. Methods 2013, 10, 641-646. [CrossRef] [PubMed]

(C) 2018 by the authors. Licensee MDPI, Basel, Switzerland. This article is an open access article distributed under the terms and conditions of the Creative Commons Attribution (CC BY) license (http:/ / creativecommons.org/licenses/by/4.0/). 